\title{
STRATEGY TO IMPROVE ADMINISTRATIVE SERVICES AT THE OFFICE OF RELIGIOUS AFFAIRS, NORTH GALESONG DISTRICT, TAKALAR INDONESIA
}

\author{
By \\ Nawir Rahman ${ }^{1}$, Nurfadilah Fajri Hurriyah ${ }^{2}$, Risma Niswaty ${ }^{3}$, Sitti Hardiyanti Arhas ${ }^{4}$ \\ ${ }^{1}$ STKIP Pembangunan Indonesia \\ 2,3,4 Universitas Negeri Makassar \\ Email: ${ }^{1}$ nawir.rahman05@gmail.com, ${ }^{2}$ nurfd1@gmail.com, risma.niswaty@unm.ac.id, ${ }^{3}$ hardiyantiarhas@unm.ac.id
}

\begin{abstract}
Article Info
Article history:

Received Nov 17, 2021

Revised Dec 20, 2021

Accepted Jan 28, 2022

\section{Keywords:}

Strategy

Improvement

Administrative Services

ABSTRACT

This study aims to determine the strategy for improving administrative services at the Office of Religious Affairs, North Galesong District, Takalar Regency. This type of research is descriptive research with a qualitative approach. Data collection techniques were carried out through observation, interviews and documentation. The data analysis technique used consisted of data condensation, data presentation and conclusion drawing. The results showed that the Strategy for Increasing Administrative Services at the Office of Religious Affairs, North Galesong District, Takalar Regency can be seen from five service improvement strategies, namely (1) Core Strategy, all employees have understood the goals and functions and their respective duties are in accordance with $S O P$, several types of services are not implemented due to Covid-19. (2) Consequences Strategy, does not apply a reward system, the community appreciates (reward) employees who help them voluntarily, minimizing sanctions. (3) Customer Strategy, services provided are based on needs, services are in accordance with SOPs, implementon line systems on the SIMKAH application, facilities are available, security guarantees and one-stop services. (4) Control Strategy (Supervision Strategy), having full trust in employees, conveying and finding out what the community needs in administrative services at the Religious Affairs Office at every meeting at the local Camat Office or Village Office. (5) Culture Strategy, building team work, holding regular evaluation meetings and with disciplined leaders able to improve administrative services. The supporting and inhibiting factors can be seen in the awareness factor, organization and service facilities.
\end{abstract}

Thisisan open accessarticleundertheCC BY-SAlicense.

\section{CorrespondingAuthor:}

Risma Niswaty,

Department of Public Administration,

Universitas Negeri Makassar,

Jalan Bontolangkasa, Makassar, 92222,Indonesia

Email: risma.niswaty@unm.ac.id

\section{INTRODUCTION}

Humans are essentially in addition to be ingreferredto as individual beings, they are alsoreferredto as socialbeingswho in theirlivesalwaysneedhelpfromotherstomeettheirneeds. Thisiswhatunderliestheserviceprocess as anefforttofulfill human needs[1]-[3]. Services canbe in theformofphysicalservicesoradministrativeservices. In thiscase, theintendedformofserviceispublicserviceprovidedbythegovernmenttoeverycitizen.

Service is the most visible measure of government performance[4], [5]. The public can directly assess the government's performance based on the quality of public services[6], [7] received because the quality of public services is in the interest of many people and the impact is directly felt by people from all walks of life. Success in building public service performance in a professional, effective and accountable manner will raise the positive image of the government in the eyes of its citizens[8], [9]. The community as customers of public services has needs and 
expectations for the performance of professional public service providers. The government has the responsibility and authority in determining minimum service standards.

The Office of Religious Affairs is a government agency under the auspices of the Ministry of Religion. The duties and authorities of the Office of Religious Affairs are to carry out the duties of the office of the Ministry of Religion of the city and district in the field of Islamic Religious Affairs in the District area. In order to improve the performance, services and guidance of the Islamic community, it is necessary to arrange good organizational and work procedures, as regulated in the Regulation of the Minister of [10].

Law Number 25 of 2009 concerning Public ServicesArticle 1 paragraph (1)[11] that: Public services are activities in the context of fulfilling service needs in accordance with statutory regulations for every citizen and resident of goods, services and/or administrative services provided by public service providers (Rengifurwarin et al., 2018 , p. 3).Administration is all aspects of human life that carry out a form of cooperation in order to achieve the goals that they previously set[12]. Pre-determined administrative activities are an illustration that will provide efficient and effective results. On the other hand, the lack of clarity about the administrative focus or objectives that will be implemented will certainly experience obstacles, if these obstacles cannot be overcome, they will experience failure which will eventually turn off the administrative activities concerned.

In carrying out its duties, the Office of Religious Affairs functions as organizer of statistics and documentation, organizer of correspondence, archives, household typing, Office of District Religious Affairs, executor of marriage registration, reconciliation, managing and fostering mosques, zakat, waqf, baitulmaal and social worship, population and the development of the sakinah family in accordance with the policies established by the Director General of Islamic Community Guidance based on the applicable laws and regulations[13], [14]. With clear organizational goals, the organization can play a role and be directed in carrying out its duties, so as to improve the government's ability to provide good and satisfactory administrative services.[15]. In the initial research, there were still many people who complained about the services at the Office of Religious Affairs, especially in the management of marriage registration. In addition, many people still feel that the services provided are not satisfactory, such as the delay in the issuance of marriage books based on the SOP (Standard Operational Procedure) given at the time of the marriage, inadequate facilities and infrastructure and socialization that directly involves the community and employees of the Office of Religious Affairs. North Galesong District should be carried out more often because there are still many people who do not understand the procedure and have not registered the marriage events that have occurred[16].

So that people can easily understand how and what needs to be prepared regarding administrative services at the Office of Religious Affairs, especially in North Galesong District, Takalar Regency. This can happen due to a lack of attention to employees such as providing rewards for employees on duty to improve and be able to provide better and satisfying administrative services, provide sanctions or follow up directly for employees who violate.

From the description above, it can be seen that a strategy is needed to improve services, especially in the field of administration by observing and measuring based on indicators of service improvement strategies.

\section{RESEARCH METHOD}

The research method used is descriptive using a qualitative qualitative approach to get an explanation of the reality that appears in knowing the strategy of improving the quality of administrative services. The location of this research is at the Office of Religious Affairs, North Galesong District, Takalar Regency. Sources of data in this study are primary data and secondary data. The focus of the research is based on a description of the framework, with five strategies for improving administrative services including core strategy, consequences strategy, customer strategy, control strategy and culture strategy. The procedures in this research are pre research, research implementation and report writing. Data collection techniques used are interviews, observation and documentation. The need for research instruments used is based on the purpose of this research, with instruments in the form of researchers, interview guidelines and observation guidelines (camera/video), in qualitative research the most important instrument is the researcher himself. In this study, the validity of the data was tested by holding a member check. The informants in this study were the Head of the Office of Religious Affairs in North Galesong District, Administrative Service Employees at the Office of Religious Affairs in North Galesong District, Village Imams and Hamlet Imams in North Galesong District and the North Galesong District Community who had or were receiving services at the Religious Affairs Office. The data analysis technique used in this research is Miles model data analysis, [17] namely Data Condensation, Data Presentation, Conclusion Drawing and Verification. 
International Journal of Social Science (IJSS)

Vol.1 Issue.5 February 2022, pp: 681-686

ISSN: 2798-3463 (Printed) | 2798-4079 (Online)

DOI: https://doi.org/10.53625/ijss.v1i5.1311

3. RESULTS AND ANALYSIS

\subsection{Core Strategy}

The strategy that explains the goals of the organization is called the core strategy because it relates to the core functions of a government organization. This strategy helps in clarifying the objectives which will then also clarify the role and direction of government organizations in carrying out their duties. Therefore, this strategy can increase the government's ability to create new mechanisms to define goals and strategies [12], [18].

At the Office of Religious Affairs, North Galesong District, Takalar Regency, the understanding of employees or administrative service officers about the objectives, functions and duties has been known and understood well. In addition, so that the implementation of the goals and functions of services at the Office of Religious Affairs, North Galesong District, Takalar Regency can run well and smoothly, then apply cooperation with the aim of providing convenience to the community in obtaining administrative services related to religion. The purpose and function of the service are also in accordance with the service SOP, but the employees/officers are still inadequate.

In general everything is working. However, several types of services were not carried out optimally, due to Covid-19 which required not to gather in one place. The problem that often occurs is that the files are incomplete, such as the marriage documents needed based on the existing requirements.

\subsection{Consequence Strategy}

The consequence strategy is a strategy related to the incentive system. This strategy focuses on creating consequences (both positive and negative) for the resulting performance. With these consequences there is a healthy competition among employees or other public service providers in order to increase employee performance motivation, through the application of rewards and punishments by taking into account economic risks and giving awards. [19], [20].

At the Office of Religious Affairs, North Galesong District, Takalar Regency, there is no incentive or reward system from the District Religious Affairs Office, for each punishment (sanctions / punishments) will be closed together. But there are from each catin pair (community) for each assisted by the Village Imam and the operator in the form of materials or food according to the sincerity (voluntary) of the community. The reward that is most often given by the community is food according to their sincerity. For village priests who assist in taking care of the administration, awards are given in the form of verbal speech or in the form of material voluntarily.

In addition, the Office of Religious Affairs, North Galesong District, Takalar Regency also minimizes the imposition of sanctions on employees who violate it as long as this does not damage the system at the Office of Religious Affairs, North Galesong District, Takalar Regency. If there are employees or officers who violate, a meeting will be held and follow up.

\subsection{Consequence Strategy}

The customer strategy aims to create a service delivery system carried out by bureaucrats, so as to be able to provide an optimal level of service for the community. The ways that can be implemented are by creating a feedback system from the community, creating simple procedures, creating a pleasant and relaxing office environment, providing a place for complaints and information, creating a service system based on information technology, media and telecommunications, creating a computer system. who use the online system [21].

Based on this strategy, the Religious Affairs office, North Galesong District, Takalar Regency has provided services to the community according to their needs properly, the administrative services provided are in accordance with the service SOP, information can be obtained through the local Village Imam based on the results of meetings at the Religious Affairs Office and through socialization, writing affixed to every mosque as well as orally on the pulpits of the mosque or mushalah if there are new regulations or requirements in administrative services.

A computer system with an online system at the Office of Religious Affairs, North Galesong District, Takalar Regency can run smoothly with a smooth network on the SIMKAH application, completeness of files and employee awareness of their duties. Existing facilities are also adequate and able to assist in improving administrative services at the Office of Religious Affairs, North Galesong District, Takalar Regency.

One-stop service is available. So when people come, they will be served as soon as possible. The security guarantee provided is to serve the community well based on conditions and guaranteed. The community will submit complaints directly through the Village Imam and meet before being followed up. From some of these things it can be said that the services provided have improved and are quite satisfactory.

\subsection{Supervision Strategy}

The supervisory strategy is intended to increase the strength of the organization through organizational structuring. Through this supervisory strategy, it is hoped that it will create capability and independence as well as public trust in government offices as public service institutions and employees or employees as public servants. 
Supervision strategies can be carried out in organizational forms, empowering employees and empowering communities [1].

The Office of Religious Affairs in North Galesong District supervises by giving full trust and carrying out responsibilities for their respective duties, especially in administrative services. This can be seen from the level of community satisfaction based on the completeness of the file requirements that must be met. The administrative services provided are also in accordance with the procedures and community needs.

To find out the need for administrative services, officers or Village Imams are assigned to convey what the community needs related to administrative services at the Office of Religious Affairs, North Galesong District, Takalar Regency at every meeting or meeting at the District Office or Village Office. From these efforts, some people have understood the existing procedures and if there is something that is not understood, the community can go directly to the Village Imam.

\subsection{Cultural Strategy}

Cultural strategy aims to change the culture that can hinder the direction of a change. In other words, a culture that is oriented towards the status quo must be transformed into a culture that is open to change [22].

To realize good administrative services, the Office of Religious Affairs in North Galesong District builds teamwork, respects each other, provides advice that is able to inspire and take the time to sit together and discuss matters related to the Office of Religious Affairs. The Head of the Office of Religious Affairs also has the principle of being an example by always arriving early and holding regular evaluation meetings to improve administrative services that are better than before.

From this, the researcher concluded that the administrative services of the Office of Religious Affairs, North Galesong District, Takalar Regency had improved better with new leaders who were more disciplined and always controlled the work of each section. So as to create employees or service officers who are good and able to carry out tasks according to service standards. The Office of Religious Affairs, Galesong Utara District, Takalar Regency is able to improve administrative services with this strategy, researchers can see this from cooperation, discipline and mutual assistance if there are other parts that need help, without leaving their respective job responsibilities.

\subsection{Supporting Factors and Inhibiting Factors}

To realize good administrative services to the community, there are several factors that influence the improvement of administrative services. According to Moenir, these factors can be seen from the awareness factor, organizational factor and service facility factor. these factors are different but influence each other and together are able to realize an increase in good administrative services. Vice versa, if one of these factors does not meet and support administrative work, the service will feel less than optimal.

The supporting and inhibiting factors for improving administrative services at the Office of Religious Affairs, North Galesong District, Takalar Regency are the calm and flexibility given in making decisions about doing their respective tasks. So there is no hesitation in stepping and as long as it does not violate existing rules. Assisted by extension workers and village priests as well as the availability of the facilities needed to support the completion of the work. Officers or employees at the Office of Religious Affairs in North Galesong District still need to strengthen cooperation to make it better. It takes cooperation from the community so that all service processes can run well and smoothly.

\section{CONCLUSION}

Based on the results of research and discussion of strategies for improving administrative services at the Office of Religious Affairs, North Galesong District, Takalar Regency, it can be concluded that: Core Strategy, all employees have a good understanding of the goals and functions and duties of each so as to provide convenience to the community in administrative services, the objectives and functions of the services provided are in accordance with the SOP, several types of services are not carried out optimally because of Covid-19 which requires not to gather in one place; Consequences Strategy. do not implement an incentive or reward system, some communities appreciate employees who help them by providing food or materials voluntarily (without coercion), minimize the imposition of sanctions on employees as long as they do not damage the existing system; Customer Strategy (Customer Strategy). The Office of Religious Affairs in North Galesong District has provided services to the community based on need, the services provided are in accordance with SOPs, a computer system with an online system on the SIMKAH application, employee awareness of their duties and available facilities, security guarantees and one-stop services; Control Strategy (Supervision Strategy). The Office of Religious Affairs, Galesong Utara District, Takalar Regency gives full trust to employees, especially administrative services in carrying out their duties so that there is no doubt in making decisions when needed, convey and find out what the community needs for administrative services at the Office of Religious Affairs at every meeting at the local Camat Office or Village Office; Culture Strategy (Cultural Strategy). build teamwork, respect each other, give advice that can create 
International Journal of Social Science (IJSS)

Vol.1 Issue.5 February 2022, pp: 681-686

ISSN: 2798-3463 (Printed) | 2798-4079 (Online)

DOI: https://doi.org/10.53625/ijjss.v1i5.1311

enthusiasm and take time to sit together and discuss things that can support service improvement, hold regular evaluation meetings and with disciplined leaders able to improve administrative services; The supporting factors and inhibiting factors for improving administrative services at the Office of Religious Affairs, North Galesong District, Takalar Regency are the calm and flexibility given in making decisions about doing their respective tasks. So there is no hesitation in stepping and as long as it does not violate existing rules. Assisted by extension workers and village priests as well as the availability of the facilities needed to support the completion of the work. Officers or employees at the Office of Religious Affairs in North Galesong District still need to strengthen cooperation to make it better. It takes cooperation from the community so that all service processes can run well and smoothly.

\section{ACKNOWLEDGEMENTS}

The researcher would like to thank all those who have assisted in this research process, especially to the Office of Religious Affairs, North Galesong District, and Takalar Regency, which has allowed me to conduct research.

\section{REFERENCES}

[1] A. Ciobanu and A. Androniceanu, "Civil Servants Motivation and Work Performance in Romanian Public Institutions," Procedia Econ. Financ., vol. 30, pp. 164-174, 2015.

[2] J. E. Magdahl and D. Jordhus-Lier, "Labour internationalism and the public sector: The case of the Public Services International,” Polit. Geogr., vol. 79, p. 102146, 2020.

[3] J. Mandhani, J. K. Nayak, and M. Parida, "Interrelationships among service quality factors of Metro Rail Transit System: An integrated Bayesian networks and PLS-SEM approach," Transp. Res. Part A Policy Pract., vol. 140, pp. 320-336, 2020.

[4] R. Niswaty, S. Seha, S. H. Arhas, M. Nasrullah, and M. Darwis, "Effectiveness of BPHTB Administration Services at the Makassar City Regional Revenue Agency," Pinisi Bus. Adm. Rev., vol. 2, no. 2, pp. 89-100, 2021.

[5] R. Niswaty, H. L. AM, S. Saleh, A. Baharuddin, and S. H. Arhas, "The Implementation Effect of Industrial Work Practices on Student Work Readiness,” Pinisi Bus. Adm. Rev., vol. 1, no. 1, pp. 21-30, 2019.

[6] R. Niswaty, J. Manno, and H. Akib, "An analysis of the public service performance based on human development index in makassar city, Indonesia," Int. J. Appl. Bus. Econ. Res., vol. 13, no. 6, pp. 4421-4429, 2015.

[7] W. P. I. Sari, J. Jamaluddin, S. Saleh, and S. H. Arhas, "Influence of Compensation on Work Performance in the District Office of Bissappu, Bantaeng Regency," J. Ad'ministrare, vol. 6, no. 2, pp. 105-114, 2020.

[8] X. Islami, E. Mulolli, and N. Mustafa, "Using Management by Objectives as a performance appraisal tool for employee satisfaction," Futur. Bus. J., vol. 4, no. 1, pp. 94-108, 2018.

[9] S. Marupuru et al., "Exploring performance predictors among employees in a pharmacist-led medication management center," J. Am. Pharm. Assoc., vol. 60, no. 6, pp. 809-817, 2020.

[10] R. of the M. of R. of the R. of I. N. 34 of 2016 concerning the O. and W. P. of the S.-D. R. A. Office, Regulation of the Minister of Religion of the Republic of Indonesia No. 34 of 2016 concerning the Organization and Work Procedures of the Sub-District Religious Affairs Office. 2016.

[11] L. N. 25 of 2009 concerning P. Services, Law Number 25 of 2009 concerning Public Services. 2009.

[12] C. Sakuliampaiboon, J. N. Songkhla, and S. Sujiva, "Strategies of Information Communication and Technology Integration by Benchmarking for Primary School in Catholic (Layman) School Administration Club Bangkok Arch Diocese for Students' 21st Century Skill,” Procedia - Soc. Behav. Sci., vol. 174, pp. 1026-1030, 2015.

[13] H. Demirtel and Ö. G. Bayram, "Efficiency of Electronic Records Management Systems: Turkey and Example of Ministry of Development," Procedia - Soc. Behav. Sci., vol. 147, pp. 189-196, 2014.

[14] S. Yoo et al., "Developing a mobile epilepsy management application integrated with an electronic health record for effective seizure management," Int. J. Med. Inform., vol. 134, p. 104051, 2020.

[15] P. A. Busch, H. Z. Henriksen, and Ø. Sæbø, "Opportunities and challenges of digitized discretionary practices: a public service worker perspective," Gov. Inf. Q., vol. 35, no. 4, pp. 547-556, 2018.

[16] M. Mumtaz, "Role of civil society organizations for promoting green and blue infrastructure to adapting climate change: Evidence from Islamabad city, Pakistan," J. Clean. Prod., vol. 309, p. 127296, 2021.

[17] M. B. Miles, A. M. Huberman, and J. Saldana, Qualitative Data Analysis: A Methods Sourcebook, 3rd ed. United States of America: Sage Publications, 2014.

[18] S. Winarto and R. Niswaty, "Strategi Pengembangan Daya Tarik Wisata Balla Lompoa Di Kabupaten Gowa Provinsi Sulawasi Selatan,” J. Ad'ministrare J. Pemikir. Ilm. dan Pendidik. Adm. Perkantoran, vol. 2, no. 2, pp. 
94-100, 2015.

[19] L. I. Syafii, A. Thoyib, U. Nimran, and Djumahir, "The Role of Corporate Culture and Employee Motivation as a Mediating Variable of Leadership Style Related with the Employee Performance (Studies in Perum Perhutani)," Procedia - Soc. Behav. Sci., vol. 211, pp. 1142-1147, 2015.

[20] S. R. Rosmani, A. H. Amirullah, and S. Saleh, "Pengaruh Motivasi Kerja terhadap Kinerja Pegawai pada Dinas Kebersihan dan Pertamanan Kabupaten Soppeng," J. Off., vol. 1, no. 1, pp. 31-37, 2015.

[21] A. R. Toding, R. Niswaty, and H. Akib, "Efektivitas Pelaksanaan Sistem Informasi Manajemen pada Kantor Wahana Lingkungan Hidup Sulawesi Selatan di Kota Makassar,” J. Off., vol. 1, no. 1, pp. 71-79, 2015.

[22] B. S. Steel, J. C. Pierce, E. Berman, and J. Taylor, "Job satisfaction in Cascadia: A comparison of British Columbia, Oregon, and Washington civil servants,” Soc. Sci. J., vol. 54, no. 4, pp. 379-388, 2017. 